\title{
Mechanism of Sphingosine 1-Phosphate- and Lysophosphatidic Acid-Induced Up-Regulation of Adhesion Molecules and Eosinophil Chemoattractant in Nerve Cells
}

\author{
Richard W. Costello ${ }^{1}$, Michael Maloney ${ }^{1}$, Mazin Atiyeh ${ }^{1}$, Gerald Gleich ${ }^{2}$ and \\ Marie-Therese Walsh ${ }^{1} *$
}

1 Department of Medicine, Royal College of Surgeons in Ireland, Beaumont Hospital, Dublin 9, Ireland; E-Mails: rcostello@ rcsi.ie (R.W.C.); micmaloney@ rcsi.ie (M.M.); matiyeh@ rcsi.ie (M.A.)

2 Department of Dermatology, University of Utah, Salt Lake City, UT 84132, USA;

E-Mail: Gerald.Gleich@hsc.utah.edu

* Author to whom correspondence should be addressed; E-Mail: mtwalsh@ $@$ rcsi.ie;

Tel.: +353-1-8093803; Fax: +353-1-8093765.

Received: 8 March 2011; in revised form: 5 May 2011 / Accepted: 9 May 2011 /

Published: 17 May 2011

\begin{abstract}
The lysophospholipids sphingosine 1-phosphate (S1P) and lysophosphatidic acid (LPA) act via G-protein coupled receptors $\mathrm{S}_{1} \mathrm{P}_{1-5}$ and $\mathrm{LPA}_{1-3}$ respectively, and are implicated in allergy. Eosinophils accumulate at innervating cholinergic nerves in asthma and adhere to nerve cells via intercellular adhesion molecule-1 (ICAM-1). IMR-32 neuroblastoma cells were used as an in vitro cholinergic nerve cell model. The $\mathrm{G}_{\mathrm{i}}$ coupled receptors $\mathrm{S}_{1} \mathrm{P}_{1}, \mathrm{~S}_{1} \mathrm{P}_{3}, \mathrm{LPA}_{1}, \mathrm{LPA}_{2}$ and $\mathrm{LPA}_{3}$ were expressed on IMR-32 cells. Both S1P and LPA induced ERK phosphorylation and ERK- and $\mathrm{G}_{\mathrm{i}}$-dependent up-regulation of ICAM-1 expression, with differing time courses. LPA also induced ERK- and $\mathrm{G}_{\mathrm{i}}$-dependent up-regulation of the eosinophil chemoattractant, CCL-26. The eosinophil granule protein eosinophil peroxidase (EPO) induced ERK-dependent up-regulation of transcription of $\mathrm{S}_{1} \mathrm{P}_{1}, \mathrm{LPA}_{1}, \mathrm{LPA}_{2}$ and $\mathrm{LPA}_{3}$, providing the situation whereby eosinophil granule proteins may enhance S1P- and/or LPA- induced eosinophil accumulation at nerve cells in allergic conditions.
\end{abstract}

Keywords: lysophospholipid; neuronal; eosinophil 


\section{Introduction}

In animal models of asthma, and in many asthma patients, antigen inhalation results in inhibition of muscarinic $\mathrm{M}_{2}$ receptors on parasympathetic nerves, leading to acetylcholine release and hence mucous secretion and contraction of bronchial smooth muscle [1].

Eosinophilia is a hallmark of allergic diseases such as asthma and allergic rhinitis [2]. Eosinophils accumulate at innervating cholinergic nerves in human and animal models of allergic conditions, contributing to nerve hyperresponsiveness due to eosinophil major basic protein (MBP)-mediated $\mathrm{M}_{2}$ antagonism [3,4]. Eosinophil accumulation at airway nerves is mediated by eosinophil CCR3 receptors [5]. We have employed the neuroblastoma cell line IMR-32 as a useful in vitro model of cholinergic nerve cell function. Differentiated IMR-32 cells express neuronal muscarinic $\mathrm{M}_{2}$ receptors and release acetylcholine in response to eosinophil adhesion via nerve intercellular adhesion molecule-1 (ICAM-1) and vascular cell adhesion molecule-1 (VCAM-1) [6-8]. Adhesion results in both the release of eosinophil granule proteins and the generation of signaling events and phenotypic changes within the nerve cells [6,9-13]. Released eosinophil granule proteins [6] induce further nerve cell signaling and protection from apoptosis [12]. Thus, eosinophils influence nerve function due to direct contact via ICAM-1 and VCAM-1 and consequent release of granule proteins.

S1P and LPA are bioactive phospholipids, which exert many of their effects via G-protein coupled $\mathrm{S} 1 \mathrm{P}$ receptors $\mathrm{S}_{1} \mathrm{P}_{1}, \mathrm{~S}_{1} \mathrm{P}_{2}, \mathrm{~S}_{1} \mathrm{P}_{3}, \mathrm{~S}_{1} \mathrm{P}_{4}$ and $\mathrm{S} 1 \mathrm{P}_{5}$ and $\mathrm{LPA}$ receptors $\mathrm{LPA}_{1}, \mathrm{LPA}_{2}, \mathrm{LPA}_{3}$ and the structurally distant $\mathrm{LPA}_{4}$ respectively [14-16] as well as LPA5 which has a distinct expression pattern suggesting specific physiological functions [17]. S1P and LPA have both been implicated in various aspects of neuronal function and activity and neuronal cell intracellular signaling, including cytoskeletal reorganization, acetylcoholine release, apoptosis and neurite outgrowth or retraction [18-21].

A role for both S1P and LPA and their receptors has also been postulated in airway inflammatory responses, for example in allergy (reviewed [22,23]. Both S1P and LPA levels in bronchoalveolar lavage fluid are significantly increased 18-24 h following segmental allergen challenge in allergy patients and S1P promotes airway remodeling [24,25]. S1P is released primarily from activated platelets and activated mast cells [26]. S1P promotes airway remodeling [24] and we and others have shown that eosinophils express functional S1P receptors [27,28]. In vitro and animal studies have indicated that LPA induces eosinophil and neutrophil migration [29-31]. LPA also induces mast cell chemokine and histamine release [32,33]. Both S1P and LPA up-regulate intercellular adhesion molecule-1 (ICAM-1) in HUVECs [34]. Importantly in the context of allergy, S1P up-regulates ICAM-1 in human alveolar epithelial cells [35-37].

We hypothesized that cholinergic nerve cells would express receptors for S1P and LPA and that ligand binding to these receptors would activate intracellular signaling pathways in the nerve cells leading to transcriptional up-regulation of ICAM-1 and of members of the eosinophil eotaxin chemoattractant family. This would further implicate S1P and/or LPA in allergic symptoms by enhancing eosinophil accumulation at and adhesion to nerve cells and hence to nerve cell hyperreactivity. 


\section{Results and Discussion}

2.1. IMR32 Cells Express SIP,$S 1 P_{3}$ and $L P A_{1-3} ; S 1 P$ and LPA Induce Up-Regulation of ICAM-1 Transcription

Given that there is both an increased level and defined source of both LPA and SIP after allergen challenge we investigated the role of these lysophospholipids in an in vitro model of eosinophil/nerve cell interactions. We and others have used butyrate-differentiated IMR-32 cells as a model of cholinergic nerve function in a variety of studies [6-11,13,38,39]. They are considered to be a convenient in vitro model for studying aspects of neurobiology at the molecular and cell level.

Expression of S1P receptors $\mathrm{S}_{1} \mathrm{P}_{1}$ and $\mathrm{S}_{1} \mathrm{P}_{3}$ (Figure 1A) and of $\mathrm{LPA}_{1-3}$ (Figure 1B) was confirmed in IMR32 cells maintained in proliferation or differentiation medium by real-time PCR. No expression of $\mathrm{S}_{2} \mathrm{P}_{2}, \mathrm{~S}_{1} \mathrm{P}_{4}$ or $\mathrm{S}_{1} \mathrm{P}_{5}$ was detected after 40 cycles of $\mathrm{PCR}$ in any cells (Figure 1A); as a positive control, expression of all three of these receptors was readily detected on neutrophils (Figure 1A). All further experiments were in differentiating IMR32 cells, as these cells display a strongly cholinergic phenotype in differentiation medium $[8,24,38]$. We confirmed by Western blotting that, identically to the cDNA expression profile, differentiating IMR32 cells expressed $\mathrm{S}_{1} \mathrm{P}_{1}, \mathrm{~S}_{1} \mathrm{P}_{3}$ (Figure 1B) and $\mathrm{LPA}_{1-3}$ proteins (Figure 1B), but not $\mathrm{S}_{1} \mathrm{P}_{2}, \mathrm{~S}_{1} \mathrm{P}_{4}$ or $\mathrm{S}_{1} \mathrm{P}_{5}$. We determined by real time PCR that both S1P (Figure 1C) and LPA (Figure 1C) increased expression of ICAM-1 two- to three-fold over baseline levels, a similar order of magnitude as the positive control stimulus, TNF- (Figure 1C). However, up-regulation of ICAM-1 expression was induced more transiently by LPA (Figure 1C), compared to S1P which induced a sustained up-regulation between $30 \mathrm{~min}$ to $24 \mathrm{~h}$ (Figure 1C), similar to TNF- (Figure 1C).

\subsection{SIP and LPA Induce ERK Activation in IMR32 Cells with Different Time Courses with Consequenct $G_{i}$-Protein Coupled and ERK-Dependent Up-Regulation of ICAM-1 and/or CCL-26}

To determine the intracellular signaling mechanisms that could mediate S1P-and/or LPA-induced up-regulation of ICAM-1 on IMR32 cells, activation of the ERK MAP kinase was examined. Both S1P (Figure 2A) and LPA (Figure 2B) induced ERK phosphorylation but with different time courses. S1P induced activation of ERK was observable at $30 \mathrm{~min}$ of stimulation and remained robust at $1-2 \mathrm{~h}$ (Figure 2A) while LPA induced a more rapid ERK activation which had fallen to baseline levels between 30 and $60 \mathrm{~min}$ of stimulation (Figure 2B). To further determine intracellular mediators involved in S1P- and LPA-induced ICAM-1 up-regulation, IMR32 cells were incubated with S1P $(1 \mu \mathrm{M}, 2 \mathrm{~h})$ or LPA $(1 \mu \mathrm{M}, 30 \mathrm{~min})$. These treatment times were chosen based on the time course for ICAM-1 induction (Figure 1C) which suggested that these were the optimal times for S1P and LPA respectively. Cells were pre-treated with either the MEK inhibitor PD98059, which prevents ERK phosphorylation or with pertussis toxin (PTX), to inhibit the $\mathrm{G}_{i}$ protein, to which all the receptors

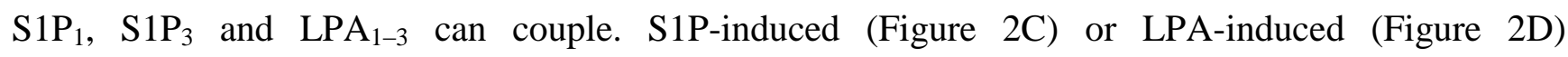
up-regulation of ICAM-1 was measured by real-time PCR and compared between cells pre-treated with PD98059 or PTX and non-pre-treated cells. This revealed that up-regulation of ICAM-1 by both S1P and by LPA was dependent on both ERK phosphorylation and on $\mathrm{G}_{\mathrm{i}}$ coupling. This is consistent with the recently demonstrated mechanism of S1P-induced up-regulation of ICAM-1 in airway epithelial cells [34]. 
Figure 1. S1P and LPA receptors in IMR-32 cells and S1P- or LPA- induced ICAM-1 transcription. IMR32 cells were plated in 6-well tissue culture dishes in differentiation medium $\left(5 \times 10^{5}\right.$ per well) then harvested for: $(\mathbf{A})$ RNA and cDNA preparation and semi-quantitative or quantitative PCR using primers for (A) $\mathrm{S}_{1} \mathrm{P}_{1-5}$ or $\mathrm{LPA}_{1-3}$ or (B) total protein preparation and Western blotting for receptors $\mathrm{S}_{1} \mathrm{P}_{1}, \mathrm{~S}_{\mathrm{P}} \mathrm{P}_{3}$ or $\mathrm{LPA}_{1-3}$. (C) IMR32 cells in differentiation medium were treated with: S1P $(1 \mu \mathrm{M})$, LPA $(1 \mu \mathrm{M})$ or TNF $(10 \mathrm{ng} / \mathrm{mL})$ for the indicated times, then harvested for RNA and cDNA preparation and real-time PCR using primers for ICAM-1 or $\beta$-actin. Results are expressed as fold increase in ICAM- $1 / \beta$-actin ratio over non-EPO treated (0) cells (set to unity). Mean \pm SEM; $* p<0.05, * * p<0.01$, significantly increased versus untreated cells.
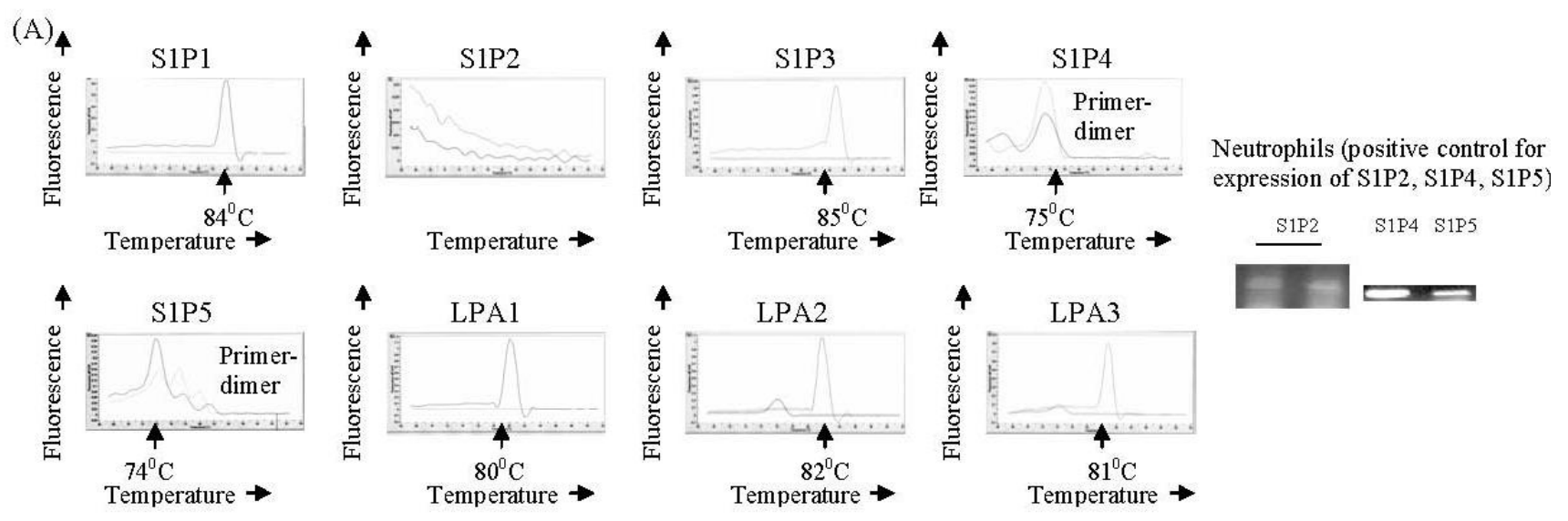

(B)

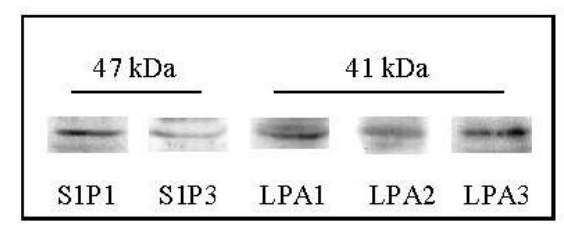

(C)

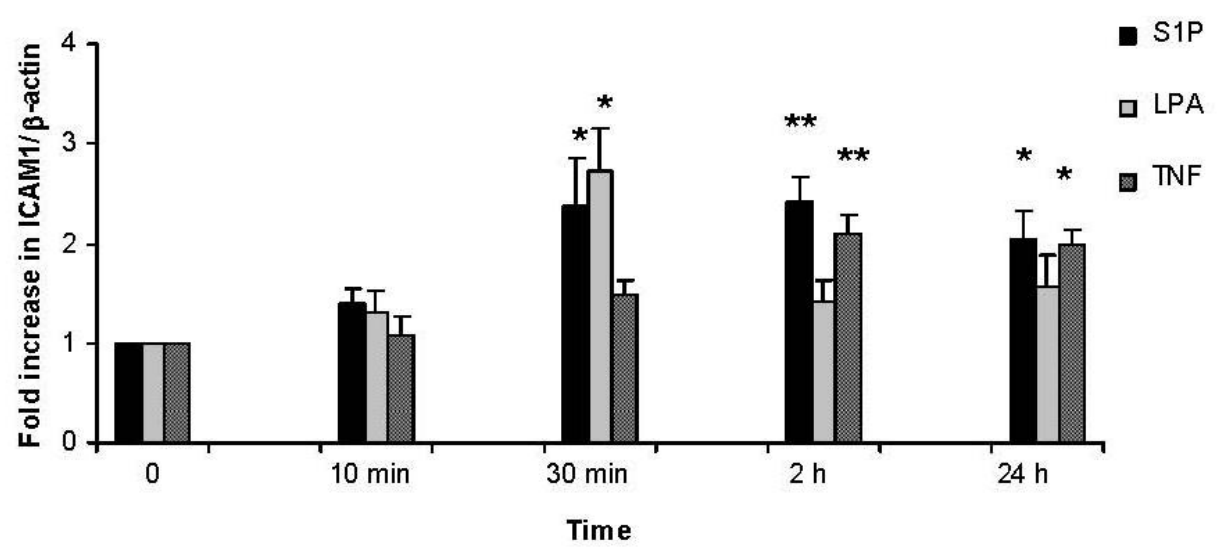

Real-time PCR was also used to monitor expression of the eosinophil chemoattractant CCL26 (eotaxin-3), normalized to $\beta$-actin expression (Figure 2E). Results indicated that at the time points shown, LPA but not S1P up-regulated CCL26 expression (Figure 2E); we have also observed no up-regulation of CCL26 by S1P at other time points (data not shown). LPA-induced CCL26 up-regulation was dependent on ERK phosphorylation and on $\mathrm{G}_{\mathrm{i}}$ coupling (Figure 2E). This is the first time that LPA but not S1P has been shown to up-regulate expression of an eosinophil chemoattractant, CCL26. These results imply that further intracellular mediators are involved in CCL26 expression, which are activated by LPA but not S1P, for example the transcription factor STAT-6 [40]. 
Figure 2. S1P and LPA induce $\mathrm{G}_{\mathrm{i}}$-mediated $\mathrm{ERK}$ phosphorylation and differential up-regulation of ICAM-1 and CCL-26. IMR32 cells in differentiation medium were treated with: S1P (A, C, E) $(1 \mu \mathrm{M})$ or LPA $(1 \mu \mathrm{M})(\mathbf{B}, \mathbf{D}, \mathbf{E})$ for the indicated times. Cells were harvested for cytoplasmic protein and subjected to Western blotting with antibody to phosphor-ERK (A, B, top panels) then ERK2 (A, B, bottom panels) for normalization Blots shown are representative of three similar experiments. Real-time PCR was carried out on cDNA from cells stimulated with S1P or LPA (both $1 \mu \mathrm{M}$ ) in the presence or absence of pre-treatment overnight with the MEK/ERK inhibitor PD98059 (50 $\mu \mathrm{M})$ or the $\mathrm{G}_{\mathrm{i}}$ protein coupling inhibitor, pertussis toxin $(\mathrm{PTX})(0.1 \mu \mathrm{g} / \mathrm{mL})(\mathbf{C}, \mathbf{D}, \mathbf{E})$, using primers for ICAM-1 (C, D) or CCL-26 (E) or $\beta$-actin $(\mathbf{C}, \mathbf{D}, \mathbf{E})$. Results are expressed as fold increase in ICAM-1/ $\beta$-actin or CCL-26/ $\beta$-actin ratio over untreated cells. Mean \pm SEM, $n=4$; $* p<0.05$, LPA-induced fold increase over untreated; ${ }^{\dagger} p<0.05$, PD98059 or PTX-induced reduction in LPA-mediated CCL26 up-regulation. Panel F shows that the baseline absolute ratio of ICAM-1 or CCL-26 to $\beta$-actin is not significantly different in the presence of either inhibitor pre-treatment.

(A)

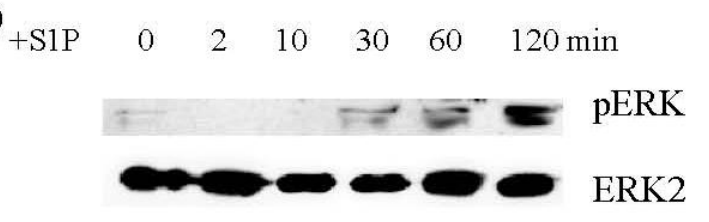

(C)

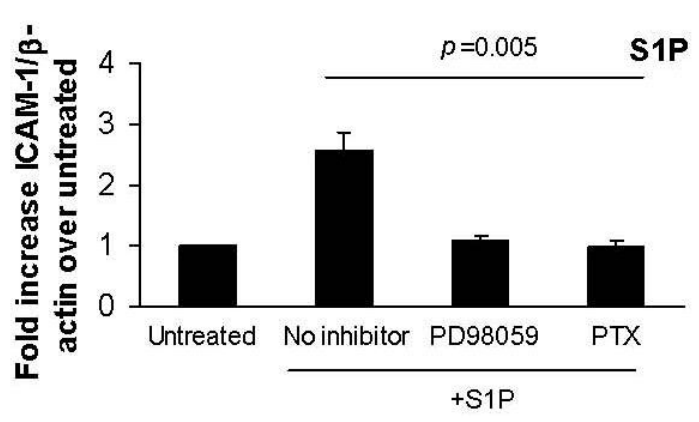

(E)

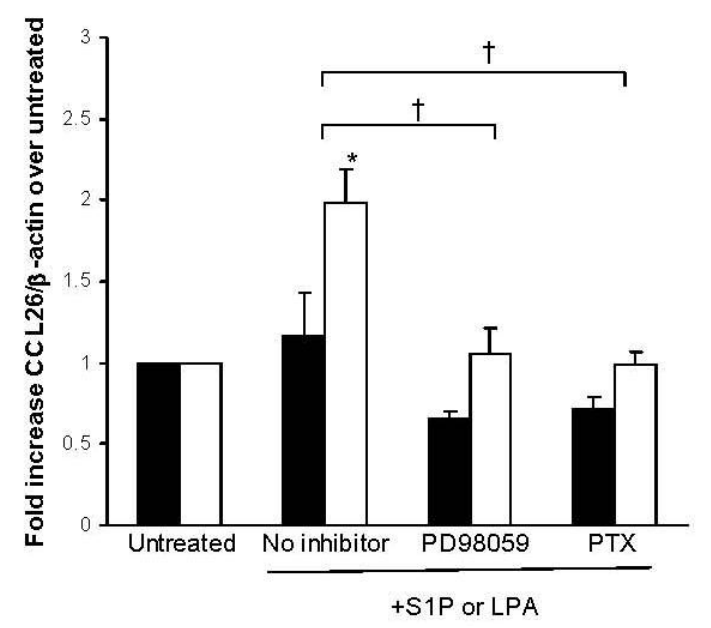

(B)

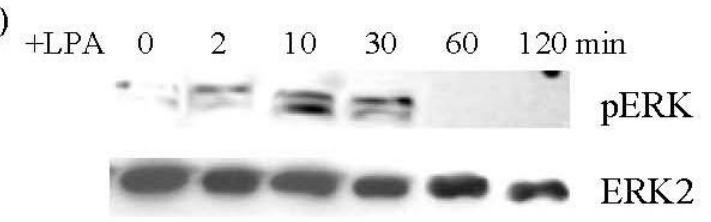

(D)

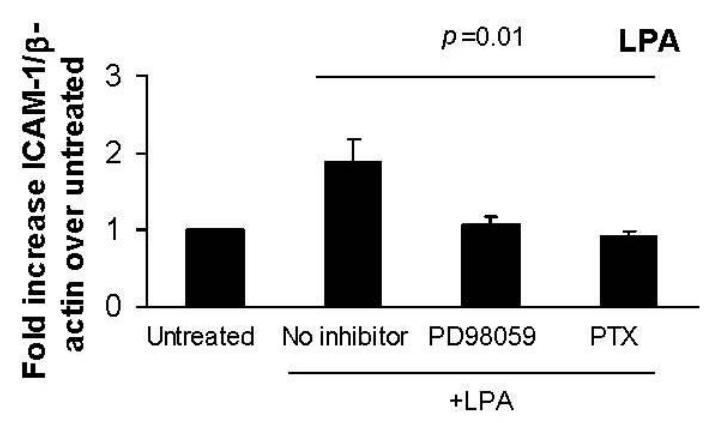

(F)

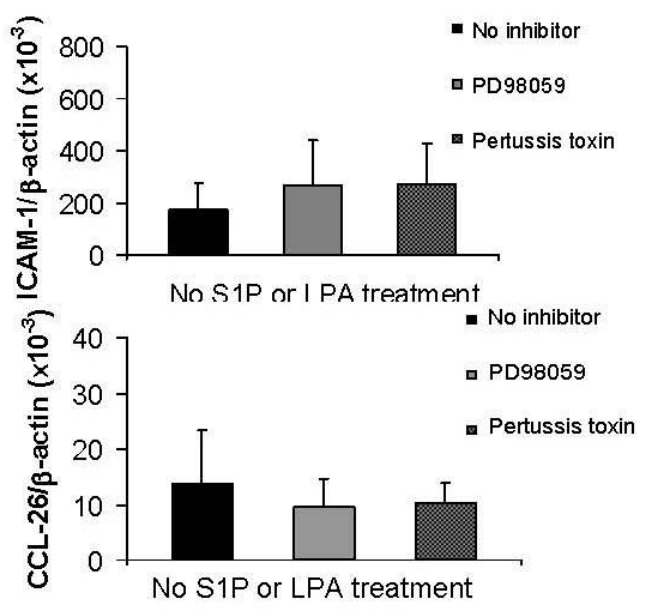


Figure 3. Eosinophil peroxidase induces ERK-dependent transcriptional up-regulation of $\mathrm{S}_{1} \mathrm{P}_{1}$ but not $\mathrm{S}_{1} \mathrm{P}_{3}$ in IMR32 cells. IMR32 cells in differentiation medium were pre-treated or not overnight with PD98059 $(50 \mu \mathrm{M})$. Cells were then treated with eosinophil peroxidase (EPO) $(1 \mu \mathrm{g} / \mathrm{mL})$ for the indicated times then harvested for RNA and cDNA preparation and real-time PCR using primers for: (A) $\mathrm{S}_{1} \mathrm{P}_{1}$ or (B) $\mathrm{S}_{1} \mathrm{P}_{3}$ or $\beta$-actin (A and $\left.\mathbf{B}\right)$. Results are expressed as EPO-induced fold increase in S1P receptor/ $\beta$-actin ratio over non-EPO treated cells harvested at the same time as the 24 hour time point, which are set to unity. Inserts show absolute values of S1P receptor versus $\beta$-actin in non-EPO-treated cells, cultured in the presence or absence of PD98059 pre-treatment, and harvested at the same time as the $24 \mathrm{~h}$ time point cells. Mean $\pm \mathrm{SEM} ; * p<0.05$, *** $p<0.001$, EPO-induced fold increase in $\mathrm{S}_{1} \mathrm{P}_{1}$ over untreated; ${ }^{\dagger} p<0.05$, ti† $p<0.001$, PD98059-induced reduction in EPO-mediated S1P 1 up-regulation.
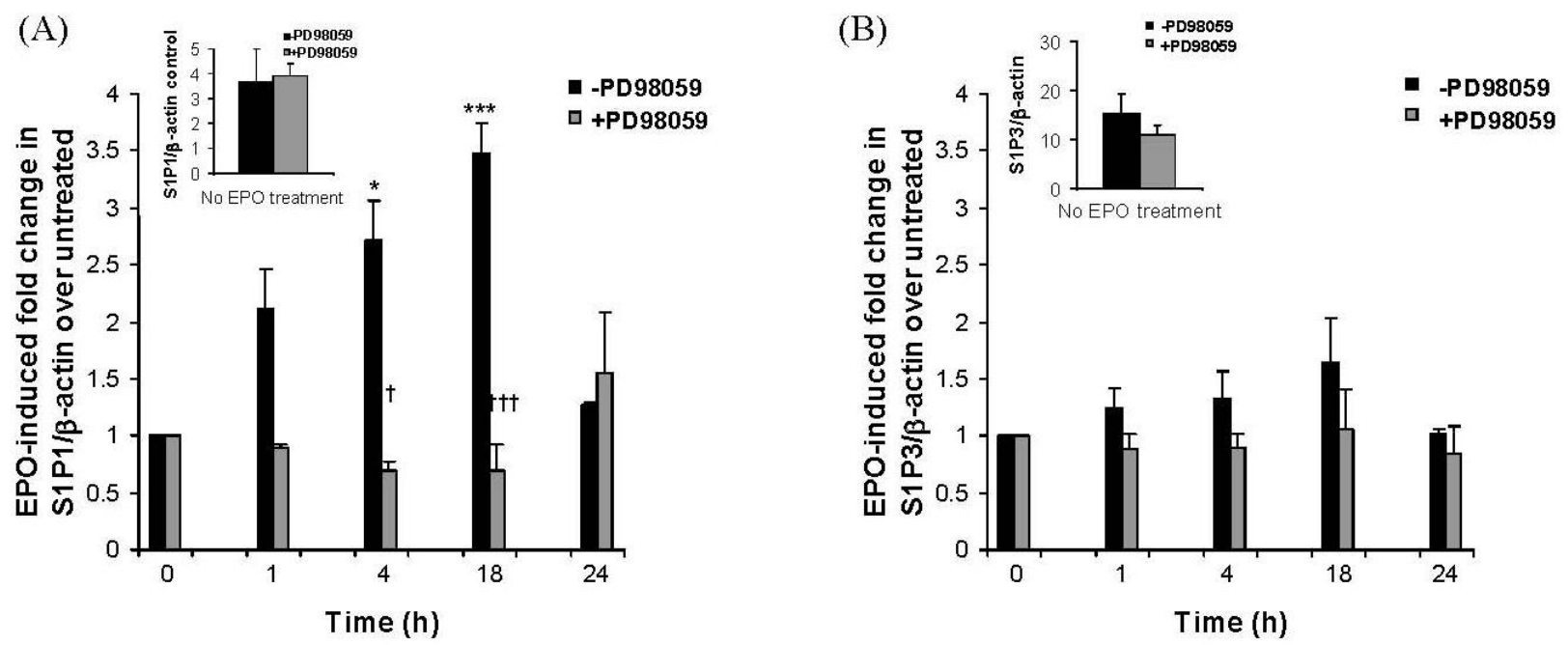

Our previous studies have shown that eosinophils accumulate at cholinergic nerves in human and animal models of allergic conditions such as asthma and rhinitis [41]. In vitro, eosinophils adhere to primary nerve cells and to differentiated IMR-32 cells via the adhesion molecules ICAM-1 and VCAM-1, with implications for nerve cell cholinergic phenotype and survival [8-13,38]. In a guinea pig model of asthma, accumulation of eosinophils at nerves was significantly decreased by treatment with CCR3 antagonist prior to antigen inhalation [5]. CCR3 antagonism also consequently reduced antigen-associated loss of $\mathrm{M}_{2}$ receptor function [5]. LPA induced up-regulation of expression of CCL26 message in differentiated IMR-32 cells; CCL26 (eotaxin-3) is a CCR3 agonist, which is up-regulated in asthmatics following allergen challenge [42] CCL26 rather than CCL11 (eotaxin-1) or CCL24 (eotaxin-2) is therefore suggested to be responsible for continuing eosinophil recruitment at later stages following allergen challenge. Furthermore, both S1P and LPA induced up-regulation of ICAM-1. Thus S1P and LPA induce conditions whereby eosinophil migration and adhesion to nerve cells would be favoured. In the context of allergy, this suggests a previously unrecognized role for these lysophospholipids in promotion of eosinophil interaction with nerves and hence nerve cell hyperreactivity, with its associated bronchoconstriction. 
Figure 4. Eosinophil peroxidase induces ERK-dependent transcriptional up-regulation of $\mathrm{LPA}_{1}, \mathrm{LPA}_{2}$ and $\mathrm{LPA}_{3}$ in IMR32 cells. IMR32 cells in differentiation medium were pre-treated or not overnight with PD98059 (50 M). Cells were then treated with eosinophil peroxidase (EPO) $(1 \mu \mathrm{g} / \mathrm{mL})$ for the indicated times then harvested for RNA and cDNA preparation and real-time PCR using primers for: (A) $\mathrm{LPA}_{1}$ or (B) $\mathrm{LPA}_{2}$ or $(\mathbf{C}) \mathrm{LPA}_{3}$ or $\beta$-actin (A, B and $\mathbf{C}$ ). Results are expressed as EPO-induced fold increase in LPA receptor/ $\beta$-actin ratio over non-EPO treated cells harvested at the same time as the $24 \mathrm{~h}$ time point, which are set to unity. Inserts show baseline absolute values of LPA receptor versus $\beta$-actin in non-EPO treated cells, cultured in the presence or absence of PD98059 pre-treatment, and harvested at the same time as the 24 hour time point cells. Mean \pm SEM; $* p<0.05$, *** $p<0.001$, EPO-induced fold increase in LPA receptor over untreated; ${ }^{\dagger} p<0.05,{ }^{\dagger \dagger} p<0.001$, PD98059-induced reduction in EPO-mediated $\mathrm{S}_{1} \mathrm{P}_{1}$ up-regulation.

(A)

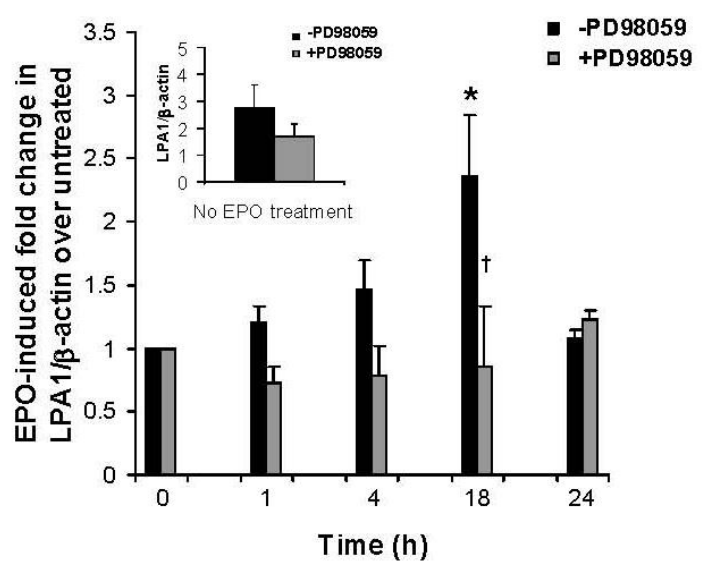

(B)

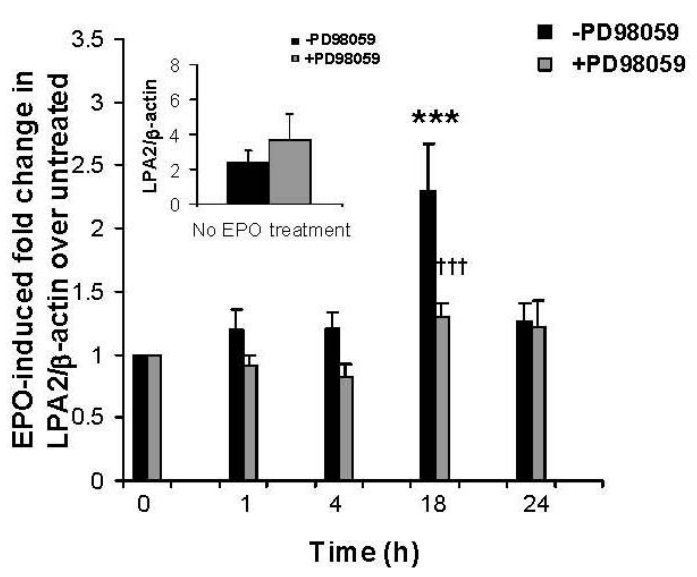

(C)

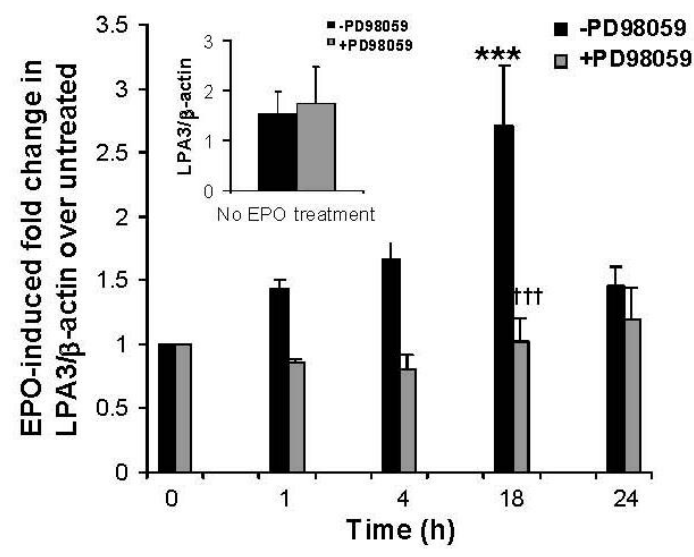

2.3. The Eosinophil Granule Protein EPO Induces Up-Regulation of $S 1 P_{1}, L P A_{1}, L P A_{2}$ and $L P A_{3}$ Receptors Expression

We have previously shown that eosinophil adhesion to IMR32 cells induces eosinophil degranulation and release of granule proteins, including eosinophil peroxidase (EPO) [8-10]. To determine whether released eosinophil granule protein could increase expression of IMR32 S1P or LPA receptors, nerve cells were treated with eosinophil peroxidase (EPO) $(1 \mu \mathrm{g} / \mathrm{mL})$ for 1, 4, 18 or 24 $\mathrm{h}$ in the presence or absence of PD98059. Real-time PCR was used to monitor the expression of $\mathrm{S}_{1} \mathrm{P}_{1}$ 
and $\mathrm{S}_{1} \mathrm{P}_{3}$ receptors (Figure 3) or $\mathrm{LPA}_{1}, \mathrm{LPA}_{2}$ and $\mathrm{LPA}_{3}$ receptors (Figure 4). EPO significantly enhanced expression of $\mathrm{S} \mathrm{P}_{1}$ by approximately 3-4 fold between 4-18 h of stimulation (Figure $3 \mathrm{~A}$ ). This up-regulation was dependent on ERK activation as it was abolished in the presence of PD98059. ${\mathrm{S} 1 \mathrm{P}_{3}}_{3}$ expression was unaffected by EPO (Figure $3 \mathrm{~B}$ ). LPA 1 (Figure 4A), LPA (Figure 4B) and LPA (Figure $4 \mathrm{C}$ ) expression were all raised approximately 3 -fold at $18 \mathrm{~h}$ of stimulation, then fell back to control levels by $24 \mathrm{~h}$.

These results imply that S1P and LPA, acting via their nerve cell receptors, can promote eosinophil recruitment and adhesion and that subsequently, eosinophil adhesion and the resulting degranulation can release a factor, namely EPO, which up-regulates the LPA and S1P receptors responsible for this effect and hence perpetuate or prolong it.

In light of the results of our study, it would be of interest to determine whether antagonism of individual S1P and/or LPA receptors reduces accumulation at and/or adhesion of eosinophils to nerves in animal models of asthma, similarly to CCR3 antagonism. Up-regulation of ICAM-1 by both S1P and LPA was dependent on $\mathrm{G}_{\mathrm{i}}$-coupling, as was LPA-induced up-regulation of CCL26. All the receptors IMR-32-expressed receptors, $\mathrm{S}_{1}, \mathrm{~S} 1 \mathrm{P}_{3}, \mathrm{LPA}_{1}, \mathrm{LPA}_{2}$ and $\mathrm{LPA}_{3}$, couple to $\mathrm{G}_{\mathrm{i}}$. Definitive receptor identification awaits further studies utilizing receptor-specific ligands or multiple siRNA technology, which was considered impractical for this work given the abundance of the specific receptors.

\section{Experimental Section}

IMR32 nerve cell culture: The human cholinergic neuroblastoma cell line IMR32 was depleted of fibroblasts, as described previously [10]. The cells were maintained in culture in proliferation medium (DMEM Plus Glutamax, 5\% FCS, $100 \mathrm{U} / \mathrm{mL}$ penicillin/streptomycin; GIBCO ${ }^{\circledR}$ Invitrogen, Paisley, $\mathrm{UK}$ ) at $37{ }^{\circ} \mathrm{C}$ in an atmosphere of $5 \% \mathrm{CO}_{2}$. On achieving confluence, cells were plated at a density of $5 \times 10^{5} /$ well in 6-well cell culture dishes and grown in proliferation medium for $48 \mathrm{~h}$. Proliferation media was then replaced by differentiation medium (DMEM Plus Glutamax, 2\% FCS, 2 mM sodium butyrate (Sigma, Poole, UK), $100 \mathrm{U} / \mathrm{mL}$ penicillin/streptomycin) and cells were used for experimentation after a further 6 days. In some experiments, individual wells were maintained in proliferation medium in parallel with the differentiating cells.

mRNA Analysis: Total RNA was isolated from the cells with TRI reagent ${ }^{\mathrm{TM}}$ (Sigma), according to the manufacturer's instructions. For both quantitative LightCycler ${ }^{\mathrm{TM}}$ PCRs (Roche, Mannheim, Germany) and semiquantitative RT-PCRs, $1 \mu \mathrm{g}$ of RNA was reverse transcribed with AMV reverse transcriptase and oligo-dT primer using a 1st strand cDNA synthesis kit (Roche), according to the manufacturer's instructions.

Semi-quantitative RT-PCR analysis of cDNA preparations was carried out in $50 \mu \mathrm{L}$ reactions with Taq-DNA polymerase for $\mathrm{S}_{1} \mathrm{P}_{1-5}$ or $\mathrm{LPA}_{1-3}$, using the primers sets (MWG Biotech/Eurofins AG, Ebersberg, Germany) outlined in Table 1. PCR conditions were: $94{ }^{\circ} \mathrm{C}, 4 \mathrm{~min}(1 \mathrm{cycle}) ; 94{ }^{\circ} \mathrm{C}, 1.5 \mathrm{~min}$, $54{ }^{\circ} \mathrm{C}, 1.5 \mathrm{~min}, 72{ }^{\circ} \mathrm{C}, 2 \mathrm{~min}(25-40$ cycles $) ; 72{ }^{\circ} \mathrm{C}, 10 \mathrm{~min}$ ( 1 cycle). PCR products were separated by $1.5 \%$ agarose gel electrophoresis and photographed under UV illumination. 40 cycles of PCR were carried out to verify absence of $\mathrm{S}_{1} \mathrm{P}_{2}, \mathrm{~S}_{1} \mathrm{P}_{4}$ and $\mathrm{S}_{1} \mathrm{P}_{5}$. 
Table 1. Primers used in this study.

\begin{tabular}{|c|c|c|}
\hline Gene & $\begin{array}{c}\text { Primer Sequence } \\
\end{array}$ & Amplicon Length (Base Pairs) \\
\hline S1P1 & $\begin{array}{l}\text { 5'-ATCGTCCTGAGCGTCTTCAT-3' (forward) } \\
\text { 5'-CCAGGAAGTACTCCGCTCTG-3' (reverse) }\end{array}$ & 95 \\
\hline S1P2 & $\begin{array}{l}\text { 5'-CCAAGCATTATGTGCTGTGC-3' (forward) } \\
\text { 5'-CAGAAGGAGGATGCTGAAGG-3' (reverse) }\end{array}$ & 186 \\
\hline S1P3 & $\begin{array}{l}\text { 5'-ACCAGTACGTGGGGAAGTTG-3' (forward) } \\
\text { 5'-GGCAATCAAAACCATCAGGT-3' (reverse) }\end{array}$ & 105 \\
\hline S1P4 & $\begin{array}{l}\text { 5'-CCAAGCGCTACATCCTCTTC-3 (forward) } \\
\text { 5'-CAGAGGTTGGAGCCAAAGAC-3' (reverse) }\end{array}$ & 221 \\
\hline S1P5 & $\begin{array}{l}\text { 5'-ACAACTACACCGGCAAGCTC-3' (forward) } \\
\text { 5'-GCCCCGACAGTAGGATGTT-3' (reverse) }\end{array}$ & 218 \\
\hline LPA1 & $\begin{array}{l}\text { 5'-ATTTCACAGCCCCAGTTCAC-3' (forward) } \\
\text { 5'-CACCAGCTTGCTGACTGTGT-3' (reverse) }\end{array}$ & 106 \\
\hline LPA2 & $\begin{array}{l}\text { 5'-CTGCTCCTGGATGGTTTAGG-3' (forward) } \\
\text { 5'-CTCGGCAAGAGTACACAGCA-3' (reverse) }\end{array}$ & 95 \\
\hline LPA3 & $\begin{array}{l}\text { 5'-TTGCCTCTGCAACATCTCTG-3' (forward) } \\
\text { 5'-ATGATGAGGAAGGCCATGAG-3 (reverse) }\end{array}$ & 82 \\
\hline ICAM-1 & $\begin{array}{l}\text { 5'-CAAGGCCTCAGTCAGTGTGA-3' (forward) } \\
\text { 5'-CCTCTGGCTTCGTCAGAATC-3' (reverse) }\end{array}$ & 129 \\
\hline CCL26 & $\begin{array}{l}\text { 5'-CCTCCTGAGTCTCCACCTTG-3' (forward) } \\
\text { 5'-TGGGAGCAGCTGTTACTGGT-3' (reverse) }\end{array}$ & 115 \\
\hline -actin & $\begin{array}{l}\text { 5'-GGACTTCGAGCAAGAGATGG-3' (forward) } \\
\text { 5'-AGGAAGGAAGGCTGGAAGAG-3' (reverse) }\end{array}$ & 118 \\
\hline
\end{tabular}

Quantitative RT-PCR analysis was carried out on the LightCycler ${ }^{\mathrm{TM}}$ (Roche) using fast start Taq DNA polymerase containing the double-stranded DNA binding dye SYBR Green 1 as in [38]. Primers are shown in Table 1 . The samples were denatured at $95{ }^{\circ} \mathrm{C}$ for $15 \mathrm{~min}$ followed by $35-40$ cycles of denaturation, annealing and extension at $95{ }^{\circ} \mathrm{C}$ for $15 \mathrm{~s}, 55^{\circ} \mathrm{C}$ for $25 \mathrm{~s}$, and $72{ }^{\circ} \mathrm{C}$ for $11 \mathrm{~s}$ (ICAM-1, $\mathrm{CCL} 26, \mathrm{~S}_{1} \mathrm{P}_{1}, \mathrm{~S}_{1} \mathrm{P}_{2}, \mathrm{~S}_{1} \mathrm{P}_{3}, \mathrm{~S}_{1} \mathrm{P}_{4}, \mathrm{~S}_{1} \mathrm{P}_{5}, \mathrm{LPA}_{1}, \mathrm{LPA}_{2}, \mathrm{LPA}_{3}$ ), or $95{ }^{\circ} \mathrm{C}$ for $15 \mathrm{~s}, 5{ }^{\circ} \mathrm{C}$ for $20 \mathrm{~s}$, and $72{ }^{\circ} \mathrm{C}$ for $20 \mathrm{~s}$ (-actin). Characteristic melting curves were obtained at the end of amplification by cooling the samples to $65{ }^{\circ} \mathrm{C}$ for $15 \mathrm{~s}$ followed by further cooling to $40{ }^{\circ} \mathrm{C}$ for $30 \mathrm{~s}$. Serial 10 -fold dilutions were prepared from individual PCR products, which were then used as standards to plot against the unknown samples. Quantification of data was analyzed using the LightCycler ${ }^{\mathrm{TM}}$ analysis software, and values were normalized to the level of $\beta$-actin expression for each sample on the same template cDNA. Results for induction over baseline values of ICAM-1 or CCL26 expression by S1P $(1 \mu \mathrm{M})$ or LPA $(1 \mu \mathrm{M})$ were obtained; in some experiments fold induction was compared between untreated, differentiated IMR32 cells versus cells pre-treated overnight with the MEK/ERK inhibitor PD98059 (Sigma) $(50 \mu \mathrm{M})$ or with pertussis toxin (Sigma) $(0.1 \mu \mathrm{g} / \mathrm{mL})$. Results for induction over baseline values of $\mathrm{S}_{1} \mathrm{P}_{1}, \mathrm{~S}_{1} \mathrm{P}_{3}, \mathrm{LPA}_{1}, \mathrm{LPA}_{2}$ or $\mathrm{LPA}_{3}$ by EPO $(1 \mu \mathrm{g} / \mathrm{mL}$, various time points $)$ were also compared between untreated, differentiated IMR32 cells versus cells pre-treated overnight with the MEK/ERK inhibitor PD98059 (50 $\mu \mathrm{M})$.

Nuclear and cytoplasmic protein preparation: IMR-32 cells $\left(5 \times 10^{5}\right)$ were differentiated for 6 days with sodium butyrate as described above and then incubated with LPA or S1P for various time periods 
from 2 min to $2 \mathrm{~h}$. Nuclear and cytoplasmic extracts were isolated from IMR-32 cells, essentially as in [10]. Protein concentration was established by the Bradford method [43] and nuclear and cytoplasmic extracts stored at $-80{ }^{\circ} \mathrm{C}$.

Western blotting: Total cell protein was extracted from IMR32 cells using Tri Reagent, according to the manufacturer's instructions and quantified according to the Bradford method [43]. Total cell protein $\left(\mathrm{S}_{1} \mathrm{P}_{1-5}, \mathrm{LPA}_{1-3}\right.$ probing) or cytoplasmic protein (ERK probing) $(10 \mu \mathrm{g})$ was subjected to Western blotting as previously described [38] Membranes were incubated in blocking buffer (Dulbecco's PBS (Invitrogen) containing 0.2\% (w/v) I-block and 0.1\% (v/v) Tween-20) for $1 \mathrm{~h}$ at room temperature then incubated for $2 \mathrm{~h}$ in blocking buffer containing the individual respective HRP-conjugated primary antibody (Santa Cruz, CA, USA) (1:500 for each). Following six 5-min washes in washing buffer (PBS pH 7.4, 0.1\% (v/v) Tween-20) membranes were incubated for $1 \mathrm{~h} \mathrm{in}$ blocking buffer containing a dilution of the appropriate secondary antibody (1:10,000 dilution). Membranes were then washed 6 times for $5 \mathrm{~min}$ each and exposed to SuperSignal West Pico Chemiluminescent Substrate (Pierce Technology Inc., Rockford, IL, USA) for Western Blotting for 5 min at room temperature. Blots were then exposed to X-OMAT light sensitive film to obtain an image.

Statistical analysis: Values are expressed as mean SEM. The statistical significance of differences between proliferating and differentiating cells was evaluated by two-tail Student's $t$-test or by ANOVA, as appropriate. The Graphpad Instat program was used. A p-value of 0.05 or less was taken as significant.

\section{Conclusion}

Eosinophils accumulate at cholinergic nerves at sites of inflammation in asthma and allergic rhinitis. We have previously shown that eosinophils adhere to nerve cells via ICAM-1 [6,7]. In this study we have shown that the lysophospholipid LPA induces transcriptional up-regulation of expression of the eosinophil chemoattractant CCL26, which is up-regulated in asthmatics following allergen challenge [42] and is suggested to be responsible for continuing eosinophil recruitment at later stages following allergen challenge. Furthermore, both LPA and another lysophospholipid, S1P, induce up-regulation of ICAM-1. We and others have previously shown that S1P can also induce a direct chemoattractive effect on eosinophils [27,28]. Thus both S1P and LPA induce conditions whereby eosinophil migration and adhesion to nerve cells would be favored. In the context of allergy, this suggests a previously unrecognized role for these lysophospholipids in promotion of eosinophil interaction with nerves and hence nerve cell hyperreactivity, with its associated bronchoconstriction. Furthermore, the eosinophil granule protein EPO, induced up-regulation of the S1P receptor $\mathrm{S}_{1} \mathrm{P}_{1}$ and the LPA receptors $\mathrm{LPA}_{1-3}$. We have previously shown EPO to be released from eosinophils upon their adhesion to nerve cells via ICAM-1. Hence, the potential exists for a perpetuation of the S1P and LPA driven effects on eosinophil and nerve interaction as the EPO released from eosinophils attached to nerve cells could cause up-regulation of the S1P and LPA receptors, hence resulting in more S1P and LPA binding, more up-regulation of ICAM-1 and CCL-26 and more eosinophil accumulation. 


\section{References}

1. Fryer, A.D.; Jacoby, D.B. Plasticity of cholinergic and tachykinergic nerves: The convergence of the twain. Am. J. Physiol. Lung Cell. Mol. Physiol. 2002, 283, L907-L908.

2. Rothenberg, M.E.; Hogan, S.P. The eosinophil. Annu. Rev. Immunol. 2006, 24, 147-174.

3. Evans, C.M.; Fryer, A.D.; Jacoby, D.B.; Gleich, G.J.; Costello, R.W. Pretreatment with antibody to eosinophil major basic protein prevents hyperresponsiveness by protecting neuronal M2 muscarinic receptors in antigen-challenged guinea pigs. J. Clin. Invest. 1997, 100, 2254-2262.

4. Sheahan, P.; Walsh, R.M.; Walsh, M.A.; Costello, R.W. Induction of nasal hyper-responsiveness by allergen challenge in allergic rhinitis: the role of afferent and efferent nerves. Clin. Exp. Allergy 2005, 35, 45-51.

5. Fryer, A.D.; Stein, L.H.; Nie, Z.; Curtis, D.E.; Evans, C.M.; Hodgson, S.T.; Jose, P.J.; Belmonte, K.E.; Fitch, E.; Jacoby, D.B. Neuronal eotaxin and the effects of CCR3 antagonist on airway hyperreactivity and M2 receptor dysfunction. J. Clin. Invest. 2006, 116, 228-236.

6. Kingham, P.J.; McLean, W.G.; Sawatzky, D.A.; Walsh, M.T.; Costello, R.W. Adhesion-dependent interactions between eosinophils and cholinergic nerves. Am. J. Physiol. Lung Cell. Mol. Physiol. 2002, 282, L1229-L1238.

7. Sawatzky, D.A.; Kingham, P.J.; Court, E.; Kumaravel, B.; Fryer, A.D.; Jacoby, D.B.; McLean, W.G.; Costello, R.W. Eosinophil adhesion to cholinergic nerves via ICAM-1 and VCAM-1 and associated eosinophil degranulation. Am. J. Physiol. Lung Cell. Mol. Physiol. 2002, 282, L1279-L1288.

8. Sawatzky, D.A.; Kingham, P.J.; Durcan, N.; McLean, W.G.; Costello, R.W. Eosinophil-induced release of acetylcholine from differentiated cholinergic nerve cells. Am. J. Physiol. Lung Cell. Mol. Physiol. 2003, 285, L1296-L1304.

9. Kingham, P.J.; McLean, W.G.; Walsh, M.T.; Fryer, A.D.; Gleich, G.J.; Costello, R.W. Effects of eosinophils on nerve cell morphology and development: The role of reactive oxygen species and p38 MAP kinase. Am. J. Physiol. Lung Cell. Mol. Physiol. 2003, 285, L915-L924.

10. Walsh, M.T.; Curran, D.R.; Kingham, P.J.; Morgan, R.K.; Durcan, N.; Gleich, G.J.; McLean, W.G.; Costello, R.W. Effect of eosinophil adhesion on intracellular signaling in cholinergic nerve cells. Am. J. Respir. Cell Mol. Biol. 2004, 30, 333-341.

11. Morgan, R.K.; Kingham, P.J.; Walsh, M.T.; Curran, D.C.; Durcan, N.; McLean, W.G.; Costello, R.W. Eosinophil adhesion to cholinergic IMR-32 cells protects against induced neuronal apoptosis. J. Immunol. 2004, 173, 5963-5970.

12. Morgan, R.K.; Costello, R.W.; Durcan, N.; Kingham, P.J.; Gleich, G.J.; McLean, W.G.; Walsh, M.T. Diverse effects of eosinophil cationic granule proteins on IMR-32 nerve cell signaling and survival. Am. J. Respir. Cell Mol. Biol. 2005, 33, 169-177.

13. Curran, D.R.; Morgan, R.K.; Kingham, P.J.; Durcan, N.; McLean, W.G.; Walsh, M.T.; Costello, R.W. Mechanism of eosinophil induced signaling in cholinergic IMR-32 cells. Am. J. Physiol. Lung Cell. Mol. Physiol. 2005, 288, L326-L332.

14. Meyer zu Heringdorf, D.; Jakobs, K.H. Lysophospholipid receptors: Signalling, pharmacology and regulation by lysophospholipid metabolism. Biochim. Biophys. Acta 2007, 1768, 923-940. 
15. Noguchi, K.; Ishii, S.; Shimizu, T. Identification of p2y9/GPR23 as a novel G protein-coupled receptor for lysophosphatidic acid, structurally distant from the Edg family. J. Biol. Chem. 2003, 278, 25600-25606.

16. Rosen, H.; Goetzl, E.J. Sphingosine 1-phosphate and its receptors: An autocrine and paracrine network. Nat. Rev. Immunol. 2005, 5, 560-570.

17. Lee, C.W.; Rivera, R.; Gardell, S.; Dubin, A.E.; Chun, J. GPR92 as a new G12/13- and Gq-coupled lysophosphatidic acid receptor that increases cAMP, LPA5. J. Biol. Chem. 2006, 281, 23589-23597.

18. Buccoliero, R.; Futerman, A.H. The roles of ceramide and complex sphingolipids in neuronal cell function. Pharmacol. Res. 2003, 47, 409-419.

19. Colombaioni, L.; Garcia-Gil, M. Sphingolipid metabolites in neural signalling and function. Brain Res. Rev. 2004, 46, 328-355.

20. Fukushima, N. LPA in neural cell development. J. Cell. Biochem. 2004, 92, 993-1003.

21. Fukushima, N.; Shano, S.; Moriyama, R.; Chun, J. Lysophosphatidic acid stimulates neuronal differentiation of cortical neuroblasts through the LPA(1)-G(i/o) pathway. Neurochem. Int. 2007, 50, 302-307.

22. Oskeritzian, C.A.; Milstien, S.; Spiegel, S. Sphingosine-1-phosphate in allergic responses, asthma and anaphylaxis. Pharmacol. Ther. 2007, 115, 390-399.

23. Zhao, Y.; Natarajan, V. Lysophosphatidic acid signaling in airway epithelium: Role in airway inflammation and remodeling. Cell. Signal. 2009, 21, 367-377.

24. Ammit, A.J.; Hastie, A.T.; Edsall, L.C.; Hoffman, R.K.; Amrani, Y.; Krymskaya, V.P.; Kane, S.A.; Peters, S.P.; Penn, R.B.; Spiegel, S.; et al. Sphingosine 1-phosphate modulates human airway smooth muscle cell functions that promote inflammation and airway remodeling in asthma. FASEB J. 2001, 15, 1212-1214.

25. Georas, S.N.; Berdyshev, E.; Hubbard, W.; Gorshkova, I.A.; Usatyuk, P.V.; Saatian, B.; Myers, A.C.; Williams, M.A.; Xiao, H.Q.; Liu, M.; et al. Lysophosphatidic acid is detectable in human bronchoalveolar lavage fluids at baseline and increased after segmental allergen challenge. Clin. Exp. Allergy 2007, 37, 311-322.

26. Goetzl, E.J.; Wang, W.; McGiffert, C.; Huang, M.C.; Graler, M.H. Sphingosine 1-phosphate and its $\mathrm{G}$ protein-coupled receptors constitute a multifunctional immunoregulatory system. $\mathrm{J}$. Cell. Biochem. 2004, 92, 1104-1114.

27. Mackle, T.; Gendy, S.S.; Walsh, M.; McConn-Walsh, R.; Costello, R.W.; Walsh, M.T. Role of sphingosine 1-phosphate receptor expression in eosinophils of patients with allergic rhinitis, and effect of topical nasal steroid treatment on this receptor expression. J. Laryngol. Otol. 2008, 122, 1309-1317.

28. Roviezzo, F.; Del Galdo, F.; Abbate, G.; Bucci, M.; D’Agostino, B.; Antunes, E.; De Dominicis, G.; Parente, L.; Rossi, F.; Cirino, G.; De Palma, R. Human eosinophil chemotaxis and selective in vivo recruitment by sphingosine 1-phosphate. Proc. Natl. Acad. Sci. USA 2004, 101, 11170-11175.

29. Rahaman, M.; Costello, R.W.; Belmonte, K.E.; Gendy, S.S.; Walsh, M.T. Neutrophil sphingosine 1-phosphate and lysophosphatidic acid receptors in pneumonia. Am. J. Respir. Cell Mol. Biol. 2006, 34, 233-241. 
30. Idzko, M.; Laut, M.; Panther, E.; Sorichter, S.; Durk, T.; Fluhr, J.W.; Herouy, Y.; Mockenhaupt, M.; Myrtek, D.; Elsner, P.; Norgauer, J. Lysophosphatidic acid induces chemotaxis, oxygen radical production, $\mathrm{CD} 11 \mathrm{~b}$ up-regulation, $\mathrm{Ca}^{2+}$ mobilization, and actin reorganization in human eosinophils via pertussis toxin-sensitive G proteins. J. Immunol. 2004, 172, 4480-4485.

31. Hashimoto, T.; Ohata, H.; Honda, K. Lysophosphatidic acid (LPA) induces plasma exudation and histamine release in mice via LPA receptors. J. Pharmacol. Sci. 2006, 100, 82-87.

32. Lin, D.A.; Boyce, J.A. IL-4 regulates MEK expression required for lysophosphatidic acid-mediated chemokine generation by human mast cells. J. Immunol. 2005, 175, 5430-5438.

33. Hashimoto, T.; Ohata, H.; Momose, K.; Honda, K. Lysophosphatidic acid induces histamine release from mast cells and skin fragments. Pharmacology 2005, 75, 13-20.

34. Milara, J.; Mata, M.; Mauricio, M.D.; Donet, E.; Morcillo, E.J.; Cortijo, J. Sphingosine-1phosphate increases human alveolar epithelial IL-8 secretion, proliferation and neutrophil chemotaxis. Eur. J. Pharmacol. 2009, 609, 132-139.

35. Lee, H.; Lin, C.I.; Liao, J.J.; Lee, Y.W.; Yang, H.Y.; Lee, C.Y.; Hsu, H.Y.; $\mathrm{Wu}$, H.L. Lysophospholipids increase ICAM-1 expression in HUVEC through a Gi- and NF-kappaB-dependent mechanism. Am. J. Physiol. Cell Physiol. 2004, 287, C1657-C1666.

36. Lin, C.I.; Chen, C.N.; Lin, P.W.; Chang, K.J.; Hsieh, F.J.; Lee, H. Lysophosphatidic acid regulates inflammation-related genes in human endothelial cells through LPA1 and LPA3. Biochem. Biophys. Res. Commun. 2007, 363, 1001-1008.

37. Lin, C.I.; Chen, C.N.; Lin, P.W.; Lee, H. Sphingosine 1-phosphate regulates inflammation-related genes in human endothelial cells through S1P1 and S1P3. Biochem. Biophys. Res. Commun. 2007, $355,895-901$.

38. Durcan, N.; Costello, R.W.; McLean, W.G.; Blusztajn, J.; Madziar, B.; Fenech, A.G.; Hall, I.P.; Gleich, G.J.; McGarvey, L.; Walsh, M.T. Eosinophil-mediated cholinergic nerve remodeling. Am. J. Respir. Cell Mol. Biol. 2006, 34, 775-786.

39. Kingham, P.J.; Costello, R.W.; McLean, W.G. Eosinophil and airway nerve interactions. Pulm. Pharmacol. Ther. 2003, 16, 9-13.

40. Blanchard, C.; Durual, S.; Estienne, M.; Emami, S.; Vasseur, S.; Cuber, J.C. Eotaxin-3/CCL26 gene expression in intestinal epithelial cells is up-regulated by interleukin-4 and interleukin-13 via the signal transducer and activator of transcription 6. Int. J. Biochem. Cell Biol. 2005, 37, 2559-2573.

41. Costello, R.W.; Schofield, B.H.; Kephart, G.M.; Gleich, G.J.; Jacoby, D.B.; Fryer, A.D. Localization of eosinophils to airway nerves and effect on neuronal M2 muscarinic receptor function. Am. J. Physiol. 1997, 273, L93-L103.

42. Berkman, N.; Ohnona, S.; Chung, F.K.; Breuer, R. Eotaxin-3 but not eotaxin gene expression is upregulated in asthmatics 24 hours after allergen challenge. Am. J. Respir. Cell Mol. Biol. 2001, 24, 682-687.

43. Bradford, M.M. A rapid and sensitive method for the quantitation of microgram quantities of protein utilizing the principle of protein-dye binding. Anal. Biochem. 1976, 72, 248-254.

(C) 2011 by the authors; licensee MDPI, Basel, Switzerland. This article is an open access article distributed under the terms and conditions of the Creative Commons Attribution license (http://creativecommons.org/licenses/by/3.0/). 